\title{
The Influence of Earnings Management on Stock Return and the Role of Audit Quality as a Moderating Variable
}

\author{
Nuryaman
}

\begin{abstract}
This study aimed to examine the effect of earnings management on firm stock returns with audit quality as a moderating variable. Earnings management as measured by discretionary accruals estimated using the cross-sectional modified Jones (1991) model, audit quality is measured by the reputation of the auditor, Big 4 Audit Firm. The hypothesis of this study are: first, earnings management negatively affect stock returns; and the second there is effects of earnings management on stock return greater for companies audited by Big 4 Audit Firm compared with Non-Big 4 Audit Firm. Sample of study is manufacturing companies listed on the Indonesia Stock Exchange in 2010, as many 149 companies. Analysis model used multiple regression model. The results showed that earnings management negatively affect stock returns. Quality audit can strengthen the relationship negatively earnings management with stock return. The relationship negatively earnings management with stock return greater for companies audited by Big 4 Audit Firm compared with Non Big 4 Audit Firm. Audit Quality can moderate the relationship negatively earnings management with stock return.
\end{abstract}

Index Terms-Earnings management, discretionary accruals, audit quality.

\section{INTRODUCTION}

Investors need accurate and qualified information to conduct the analysis of stock investment in the capital market, and one of the sources of the information used is financial report. In the preparation of the financial reports of Financial Accounting Standards, states that the management can select and apply accounting policies so that the financial reports comply with the provisions of statement of Financial Accounting Standards [1]. The gap rule is often used by the management to modify the financial reports, so that the financial reports may present the earnings in accordance with the wishes of the management of the company. This action of modifying the financial reports is known as the earnings management.

The earnings management practices would result in the disclosure of fake financial information of the company, because it is not presented in accordance with the actual circumstances. This is very detrimental for the investors, as investors are unable to assess the risk and return on the investment funds appropriately. The finding of these earnings management actions can be useful as additional information for users of financial reports, and allow them to conduct precautionary measures at the time of analyzing

Manuscript received January 30, 2013; revised March 25, 2013.

Nuryaman is wirh Economic Faculty of Widyatama University, Bandung- Indonesia (e-mail: nuryaman.nuryaman@gmail.com) financial information.

Management actions to do earnings management will reduce the reliability of reported earnings [2], thus reducing the quality of earnings as the presented earnings information does not indicate the reality of actual economic, which in turn will have an impact on the stock price, because the earnings management is considered as bad news. This motivates the researchers to examine the relationship between earnings management and market return. The results of previous research on the influence of the earnings management on market return are not persistent. Some research results concluded that earnings management negatively influences on the market return [3]-[4]. However, some other researchers showed different results, which indicated that there were insignificant relationship between earnings management and market return on the issuance of financial reports [5]-[6]. The difference results of research appear, as the researchers do not consider the factor (variable) that can moderate the relationship between earnings management and market return.

Companies can use audit (financial audit) to increase the trust toward the financial information published through the financial reporting. A qualified audit will have an impact on increasing the trust of users of the financial reports toward the company's financial reports, so that the financial information can be used as a basis of economic decisionmaking. Previous studies distinguishes the quality of Auditors based on the distinction of the audit by Big 5 Public Audit Firms and non-big 5 Public Audit Firms. [6] Stated that the quality of audit had positive relationship with the quality of earnings, measured by Earnings Response Coefficient (ERC). The quality of the auditor by proxy of the auditor reputation with the assumption indicated that the higher quality of Auditors then the reputation was better.

The motivation of conducting this research is that most of the previous researches on the accrual discretionary in Indonesia do not include audit quality as one of the factors that has relevance to the practices of earnings management. Therefore, this research aims to provide empirical evidence about: (1) how is the influence of earnings management (proxied by accrual discretion) on return market, and (2) whether the audit quality (proxied by 4 big Public Audit Firms) can moderate the relationship between accrual discretionary and the market return.

\section{EARNings MANAGEMENT, StOCK RETURN, AND AUDIT QUALITY}

\section{A. Earnings Management}

According to [2], the definition of earnings management 
is "Earnings management is the choice by a manager of accounting policies, or actions affecting earnings, so as to achieve some specific reported earnings objectives". According to [7] earnings management happened when management applied a particular decision in the financial reports and transactions to change the financial reports as the basis for assessment of the performance of companies that aimed to deceive the owners or shareholders (shareholders), or to influence the outcome of contractual who relied on the reported accounting figures. Earnings management could occur because managers' discretion to choose the accounting method that would be used in the records and disclosure of private financial information.

\section{B. Stock Return}

Every investor expects high return on his or her investment. Return is the return on the results of obligation or capital investment. Market return, according to [8]: "Market Return is the results obtained from investments. Return can be either real return, which has happened, or expected return, which have not happened yet but expected to happen in the future". Abnormal Return is used to measure the market reaction against an event for which information is published as an announcement. [8] posited "Abnormal return is the excess of actual return occurs against the normal return". If the announcement contains information, then the market is expected to react as the announcement is welcomed by the market. Market reaction is indicated by the existence of price changes on the concerned securities.

\section{Audit Quality}

External Auditors or independent Auditors are professional auditors who provide their services to the public, especially in the field of auditing the financial reports made by their clients. The role of external auditors is giving judgment independently and professionally over the reliability and fairness of presentation of the financial reports of the company. Thus, the external auditor can be a control mechanism for management in order the management presents the financial information that is reliable, accountable, and free from accounting fraud practices. One of the proxies is often used to measure the quality of audits is the size of the Public Audit Firms, [9] Public Audit Firms have characteristics that relate to the quality of the audit that can be observed such as specialized training and peer review, rather than a non Big 6 . Research results [10] showed that the Big 6 Public Audit Firms represents the more human resources for staff training and the development of expertise in the field of specific industry than the Public Audit Firms of a non Big 6 Public Audit Firms. Further, the Big 6 Public Audit Firms have better position for negotiating with clients who intend to adopt aggressive accounting practices than the non-Big 6 Public Audit Firms.

\section{Relationship between Earnings Management and Stock Return}

The price of stocks reflects an agreement, under which the buyer agrees to buy and the sellers agree to sell it. This causes the stocks prices tend to fluctuate. Stocks price movements, that constantly change, make investors need to perform analysis in deciding to invest. One of the steps that needs to be made in investing is to do fundamental analysis. Fundamental information can generally be described as information relating to historical financial data of an enterprise. Earnings information in published financial reports is one of the keys for investors in making investment decisions.

Thus, it can be concluded that the earnings information in company, which conducts earnings management, can lead to the investors taking wrong investment decisions. High rates of earnings management in a company indicate the increasing risk, and causes lower return of shares that will be accepted by the investors. Other research has also been done by [11], in which earnings management revealed no significant effect on return market. Changes of the market return affected by the discretionary accruals only amounted to $3.2 \%$. The research was conducted to the companies listed in the index of LQ-45 in the first semester of year period 2004-2007 listed on the Indonesia Stock Exchange.

Research conducted by [12] stated that the earnings management negatively influenced on abnormal market return. The research was done at the manufacturing companies that were included in LQ-45 in Indonesia Stock Exchange (BEI) year period 2007-2008. [13] Satated that aggregate discretionary accruals positively predict future market returns and negatively correlate with current market returns. The research was carried out on the non-financial companies on the NYSE (New York Stock Exchange) during the 2004 reporting period. The study indicated that there was a relationship between the earnings managements and the market return.

\section{E. The Influence of Audit Quality on the Relationship between Earnings Management and Stock Return}

Auditing Standard Statement (PSA No. 4 of 1994) states that an audit must be carried out by one or more that own the expertise and technical training as an auditor. Based on the Auditing Standard Statement it is obvious that in order to play optimum role then the external auditor has to provide qualified audit services [14]. Qualified audit can be met if the audit is carried out by competent and independent auditors. Thus, the competence and independence are the dimensions of audit quality.

[15] developed two dimensional audit qualities. First, the audit quality that could detect errors in the presentation of the financial information. Second, wrong presented material on the financial report should be presented in the audit report.

Researchers argued that higher audit quality could reduce the uncertainty reducing noise in financial reporting indicated by higher earning response coefficient [16]. Teoh and Wong in [16] found out that ERC in clients audited by the Big 6 Public Audit Firms was higher compared to the clients audited by non- Big 6 Public Audit Firms.

[17] examined the influence of the quality of corporate governance, (quality audit as one of its dimensions) on the market value of 154 Brazilian companies listed at the stock exchange in 2002. Their findings indicated a positive influence of CG quality on the market value of the company. [18] proved that corporate governance index as a whole was an important thing and became one of the cause factors that 
could explain the market value for independent companies in Indonesia. [18] discovered the existence of a positive relationship between corporate governance and company performance as measured by Return On Assets (ROA) and Price to Book Value (PBV).

[15] conducted a study about the relationship between the audit quality and the earnings management of IPO enterprise in financial reporting period from 1999 up to 2002 in Taiwan. The submitted hypothesis were: first, the earnings management of the company (during the IPO) with a Big five auditing firms was lower than companies with non-Big five auditing firms; Second, the company's earnings management (during the IPO) audited by Public Audit Firms of specialization industry was lower than earnings management companies audited by Public Audit Firms of non-specialization industry. The results of his research indicated that audit firm size had a negative relationship with earnings management.

According to Efficient markets hypothesis of the halfstrong shape, the prices of stock securities reflect all information related to the company, including the present and future prospect of the financial performance. Publication of financial information in the form of earnings information obtained in a given period will affect the expectation of investors concerning to the company's ability to make profits in the future, and will be reflected in changes in the stock price of concerned companies in the capital markets. By seeing that the ERC value of the stock is influenced by the quality of the reported earnings of companies and perceptions regarding the quality of the earnings, it can also be influenced by the Public Audit Firms auditing the company.

\section{PRoblem STATEMENT}

Based on the description on the face of the purpose of this study was to examine: (1) The effect of earnings management on stock returns, and (2) The effect of quality audit as a moderating variable on the relationship of earnings management with stock returns

\section{MEthodology}

\section{A. Sample and Procedures}

The sampling method in this study using purposive sampling method. Sample selection criteria are: (1) The companies listed in the Indonesia Stock Exchange in the Year 2010 (2) Delivering the financial report to the Stock Exchange for the period in 2010. The sample used in this study a number of 149 manufacturing companies listed on the Stock Exchange.

\section{B. The Measuring Variables Earnings Management}

This research applies the modified Jones model to determine the earnings management, using cross section approaches developed by [19]). This approach is used to determine the value of earnings management or abnormal accruals, The equation is used as follows:

Calculating Total Accruals (TAC):
TACt $/$ TAt- $1=\alpha 1(1 /$ TAt- 1$)+\alpha 2(\Delta$ sales $t /$ TAt- 1$)+$ $\alpha 3$ (PPET / TAt-1)

Description: TACt: Total Accruals firm in period tTAt-1: Total assets in period t- $1 \Delta$ salest: Change in net sales of the company in period tPPEt: fixed assets of the company in period t $\alpha 1 \alpha 2 \alpha 3$ : Parameter specific company in period $t$

Calculating Non-Discretionary Accruals (NDTAC) NonDiscretionary Accruals is calculated using the formula:

$$
\begin{aligned}
& \text { NDTACt }=\alpha 1(1 / \text { TAt }-1)+\alpha 2(\Delta \text { Salest }-\Delta \text { RECt }) / \text { TAt- } \\
& 1+\alpha 3(\text { PPEt } / \text { TAt }-1)
\end{aligned}
$$

Description: NDTACt: Non-Discretionary Accruals firm in period tTAt $-1 \quad$ : Total assets in period $t-1 \Delta$ salest: Change in net sales of the company in period $t \triangle R E C t$ : Changes in the company's net accounts receivable at period tPPEt: fixed assets of the company in period t $\alpha 1 \alpha 2 \alpha 3$ : Parameter specific company in period $t$

Calculating Discretionary Accruals (DA) as follow :

$$
\text { DAt }=\text { TACt } / \text { TAt }-1-\text { NDTACt }
$$

In which:

DAt $=$ abnormal accrual or discretionary accrual

TACt/Tat $1=$ Total Accruals in t periode

NDTACt $=$ Non Discreation Accruals in $\mathrm{t}$ periode

Stock Return

The dependent variable in this study is the stock return. In this study, abnormal stock returns using indicators of return. Abnormal return is used to measure the market reaction to an event (event) whose information is published as an announcement. The following are the steps taken in the calculation of abnormal return :

(1) Abnormal Return Abnormal Return is the difference between the actual return occurred with return expectations, calculated using the formula:

$$
\mathrm{ARt}=\mathrm{Rt}-\mathrm{E}(\mathrm{Rt})
$$

Description: ARt: Abnormal stock return in period tRt: Return actual stock in period $\mathrm{tE}(\mathrm{Rt})$ : Return expectations of the stock in period $t$

(2) Actual Return Return is actually a return that occurs in a given period which is the current price difference with the previous price. Actual return measured by the total return is the overall return of an investment. Data used daily stock prices. Real return is calculated using the formula:

$$
\mathrm{Rt}=\mathrm{Pt}-\mathrm{Pt}-1 / \mathrm{Pt}-1
$$

Description:

Rt: Return actual stock in period tPt: share price on day tPt1: The price of shares on day $t-1$

(3) Return Expectations

Return expectations obtained using the model of marketadjusted (market-djusted model). This model assumes that the best estimator to estimate the return of a security is the market index return at that time. Using this model, it is not necessary to use the estimated period to establish the model 
estimation, because the estimated return securities is equal to the market index return. Data using the JCI (Joint Stock Price Index). Return expectations can be calculated using the formula as follow :

$$
\mathrm{E}(\mathrm{Rt})=\text { IHSGt }- \text { IHSGt-1 }
$$

Description: E (Rt): Return expectations of the stock in period tIHSGt: Composite Stock Price Index on day tIHSGt1: Composite Stock Price Index day t-1

(4) Cumulative Abnormal Return

$$
\operatorname{CAR}(\mathrm{t} 1, \mathrm{t} 2)=\Sigma \text { ARt } 1, \mathrm{t} 2
$$

\section{Description:}

CAR: Cumulative abnormal returnt1, $t 2$ : The length of the observation interval return stock or accumulation period $t 1$ to 2 Art: Abnormal stock return in period $t$

Tests performed on abnormal return around certain period or date referred to the period of the event (event period). Event period is also called the period of observation / window events (event window). While the so-called period of estimation (estimation period) is the period prior to the event. In this research, the publication date of the financial statements is the time of the incident. The authors use the window period for 11 days ( 5 days before the event, one day when the incident, and 5 days after the event). Consideration is a short window period will minimize the confounding effect, the effect of bias that arise due to any significant event which also occurred at the same time.

\section{Control Variable Leverage}

Leverage ratio shows how much a company uses external debt to finance operations and expansion. In this study, the authors use the debt to asset ratio is given by:

Debt to asset ratio $=$ Total Liabilities $/$ Total Asset

Description: Total Liabilities: Total debt at year tTotal Assets: Total assets in year $\mathrm{t}$

Company Size Firm size is the measure of the size of a company. In this study, firm size is measured by using the total sales of the company in the study (total sales).

\section{Data Analysis}

The first model to test the effect of earnings management on stock return. The second model to test the effect of audit quality as a moderating variable on the relationship of earnings management and stock returns. The model regression equation is as follows:

The first model:

$$
\mathrm{AR}=\beta 0+\beta 1(\mathrm{DA})+\beta 2(\mathrm{LEV})+\beta 3(\mathrm{SIZE})+\varepsilon
$$

\section{Model Two:}

$$
\begin{aligned}
\mathrm{AR} & =\beta 0+\beta 4(\mathrm{DA})+\beta 5(\mathrm{AUD})+\beta 6(\mathrm{DCAUD})+\beta 7 \\
(\mathrm{LEV}) & +\beta 8(\mathrm{SIZE})+\varepsilon
\end{aligned}
$$

Description: $\beta 0$ : ConstantsAR: Stock Return (cumulative abnormal return) DA: Earnings management (discretionary accruals) LEV: Leverage (debt to asset ratio) SIZE: Firm size ( $\log$ total sales)
AUD: Audit Quality (dummy variable). 1 If the financial statements of the company audited by KAP Big 4, and 0 if audited by non-Big 4 Firm. Big 4 Firm: Ernst \& Young (EY), Pricewaterhouses Coopers (PWC), Deloitte Touche Tohmatsu, KPMG International, and Audit Firm is affiliated with Big 4 Audit Firm.

DCAUD: Interaction variable quality audits with earnings management. $\varepsilon$ : error, other variables that are not included in the study

\section{RESUlTS AND DisCUSSION}

According to the Table I can be described that discretionary accrual variable (DA) sample firms have an average of 0.03 (3\%) with a standard deviation of 0441 . Average Leverage (LEV) company of 0.61 with a standard deviation of 0.506 . The average value of $\log$ sales 12.07 . The average of stock return close to 0 , because the positive stock returns with a negative stock returns are relatively the same as the standard deviation is 0.008 .

TABLE I: DESCRIPTIVE STATISTICS

\begin{tabular}{llrrrr}
\hline & N & Minimum & Maximum & Mean & Std. Deviation \\
\hline DA & 149 & -2 & 4 & .03 & .441 \\
\hline LEV & 149 & 0 & 3 & .61 & .506 \\
\hline SIZE & 149 & 9 & 14 & 12.07 & .736 \\
\hline AUD & 149 & .00 & 1.00 & .4027 & .49209 \\
\hline AR & 149 & 0 & 0 &,- 000127 & .008 \\
\hline Valid & 149 & & & & \\
N & & & & & \\
\hline
\end{tabular}

$\overline{\mathrm{DA}}=$ Descreationary accrual; Lev= leverage; SIZE= Log Sales, Firm Size; $\mathrm{AUD}=$ Audit Quality; AR= Stock Return

\section{Test of classical Assumptions}

To obtain the regression results in an efficient and accurate, the data must be free from violations of classical assumptions. Based on the three criteria test data underlying the classical assumptions obtained the following results: Table II seem variance inflation factor values (VIF) of less than 10 (VIF <10). So we can conclude the analysis model does not occur multicollinearity.

TABLE II: MULTICOLINIERITY TEST AND AUTOCORELATION TEST

\begin{tabular}{lc}
\hline Variable & VIF \\
\hline DA & 1.611 \\
\hline LEV & 1.427 \\
\hline SIZE & 1.268 \\
\hline AUD & 1,565 \\
\hline
\end{tabular}

Heteroscedasticity test use Glejser test [20]. In Table III it appears that all the regression coefficients of independent variables are not significant, because the value of SIG> 0.05 . It can be concluded not happen heteroscedasticity.

\begin{tabular}{cc}
$\begin{array}{c}\text { TABLE III: HETEROSCEDASTISITY TEST } \\
\begin{array}{c}\text { Independent } \\
\text { variabel }\end{array}\end{array}$ & $\mathrm{AR}$ \\
\hline $\mathrm{DA}$ & 0.15 \\
\hline LEV & 0.24 \\
\hline SIZE & 0.23 \\
\hline AUD & 0,43 \\
\hline
\end{tabular}


For normality test using the Kolmogorov-Smirnove (Singgih Santosa, 2002). Testing criteria is if the number of significance $(\mathrm{SIG})>0.05$, then the data were normally distributed. After testing the significance of the $\mathrm{SIG}>0.05$, thus the research data were normally distributed.

Hypotheses testing was done using two regression models with results like shown in Table 4 and Table 5 . The first regression equation to determine the relationship of earnings management (DA) with stock returns (AR). Regression results showed Accrual Descreation negatively related to stock return at a significance level $0.1(10 \%)$ so that the first research hypotheses is accepted, and the variable firm size (SIZE) is positively related to stock returns at 5\% significance level. These findings support the research [1][12]-[13]. These results demonstrate that earnings management practices were responded negatively by the capital market, because earnings management is not good news.

TABLE IV: COEFFICIENTS

\begin{tabular}{ccccccc}
\hline \multicolumn{7}{c}{$\begin{array}{c}\text { Unstandardized } \\
\text { Coefficients }\end{array}$} \\
Model & $\mathrm{B}$ & $\begin{array}{c}\text { Standardized } \\
\text { Error }\end{array}$ & Beta & $\mathrm{t}$ & Sig. \\
\hline $\mathrm{A}$ & -.031 & .010 & & -3.146 & .002 \\
\hline $\mathrm{DA}$ & -.002 & .001 & -.139 & -1.746 & .083 \\
\hline LEV & .000 & .001 & -.036 & -.454 & .650 \\
\hline SIZE & .003 & .001 & .257 & 3.215 & .002 \\
\hline
\end{tabular}

Note : Dependent Variable $=\mathrm{AR}=$ Abnormal return; $\mathrm{a}=$ Constanta; $\mathrm{DA}=$ Discretionary accrual; LEV= Leverage; SIZE= Firm Size (Log Sales)

The second regression equation was conducted to test the second hypotheses about the effect of audit quality (moderating variable) on the relationship of earnings management and stock returns. Regression results show the quality audit (AUD) influence positively to stock returns at the $10 \%$ significance level, indicating that the audit by a reputable Audit Firm (Big 4 Audit firm) were responded positively by capital markets.

TABLE V: COEFFICIENTS

\begin{tabular}{lcccrc}
\hline \multicolumn{7}{c}{$\begin{array}{c}\text { Unstandardized } \\
\text { Coefficients } \\
\text { Model }\end{array}$} & \multicolumn{2}{c}{$\begin{array}{c}\text { Stand. } \\
\text { Coefficients }\end{array}$} & & \\
\hline $\mathrm{A}$ & -.030 & .010 & & & \\
\hline $\mathrm{DA}$ & -.003 & .001 & -.139 & -1.748 & .043 \\
\hline LEV & .000 & .001 & -.053 & -.655 & .513 \\
\hline SIZE & .002 & .001 & .242 & 2.879 & .005 \\
\hline AUD & .002 & .001 & .040 & .467 & .076 \\
\hline DCAUD & .028 & .015 & .102 & 1.229 & .042 \\
\hline
\end{tabular}

Notes : Dependent Variable, $\mathrm{AR}=$ abnormal return;

$\mathrm{DA}=$ Descreationary accrual; Lev= leverage; SIZE= Log Sales, Firm Size; $\mathrm{AUD}=$ Audit Quality; AR $=$ Stock Return

DCAUD=Interaction variable.

The next test is intended to determine the effect of audit quality on earnings management relationship with stock returns. Regression results in Table 5 shows that the interaction variable (DCAUD) is positive with a significance level of $5 \%$ and the second hypothesis is accepted. While a relationship negatively discretionary accrual with stock return, significant at the 5\% significance level. These results prove that the market give more robust response to the Accrual discreation of companies which audited by Big 4 Audit Firm, compared to accrual descreation of companies which audited by non-Big 4 Audit Firm. In other words, the quality of the audit will strengthen the negative relationship between earnings management with stock returns. Negative relationship with stock return of earnings management is stronger for companies which audited by a Big 4 Audit Firm, when compared with the companies which audited by non-Big 4 Audit Firm.

These findings indicate that users of financial statements more trust on financial reports which audited by a reputable Firm. Audit quality will enhance the credibility of the financial statements.

\section{CONCLUSION}

Earnings management practices can reduce the credibility of accounting information, thus decreasing the confidence of users of this information in decision making equity investments. To enhance the credibility of financial information, External Auditor as external can provide fairness opinions financial statements. The purpose of this study to prove the role of auditor quality on earnings management relationship with stock returns. Based on above discussion, it can be concluded that:

Earnings management negatively affect stock returns, which means that the earnings management measures are not preferred by the stock market, by providing a lower stock price for companies with earnings management (accrual descreation) increases.

Next result shows that the positively effect of audit quality on the relationship of earnings management with stock return. In other words, audit quality may moderate the relationship negatively earnings management with stock return. These results reinforce the notion that audit quality can enhance the credibility of financial statements. The relationship negatively of earnings management with stock return is stronger if the companies audited by a reputable Audit Firm (Big 4 Audit Firm), when compared with the companies audited by non-Big 4 Audit Firm.

\section{REFERENCES}

[1] Ikatan Akuntan Indonesia (IAI), Kerangka Dasar Penyusunan dan Penyajian dan Penyajian Laporan Keuangan, Standar Akuntansi Keuangan, Salemba Empat, Jakarta, 2009.

[2] R. Scott and William, Financial Accounting Theory, Third edition, Canada, Prentice Hall. 6 th Edition. 2011.

[3] A. Yanti and Ardiati, "Pengaruh Manajemen Laba terhadap Return Saham dengan Kualitas Audit sebagai Variable Moderasi,' Simposium Nasional Akuntansi VI. Surabaya, 2003.

[4] P. Zarowin, Cohen, and Daniel, "Firms Learn Against the Wind?" Earnings Management and Stock Market Returns, Stern School of Business, New York University, 2011.

[5] L. L. D. Charme, P. H. Malatesta, and S. E. Sefcik, "Earnings anagement, Stock Isues, and shareholder lawsuits," Journal of Financial Economics, vol. 71, no. 1, pp. 27-49, 2004.

[6] S. H. Teoh and T. J. Wong, "Perceived Auditor Quality and Earnings Response Coefficient," The Accounting Review, vol. 68, no. 2, April, pp. 346-367, 1993. 
[7] P. M. Helly and J. M. Wallen, "A Review of The Earnings Management literature and Its implication for Standard Setting," Accounting Horizon, vol. 13, no. 4, pp. 365-383, 1999.

[8] J. Elton, Edwin, M. J. Gruber, S. J. Brown, and W. N. Goetzmann, "Modern Portfolio Theory and Investment Analysis," Eighth Edition, John Wiley \& Sons,Inc. 2011.

[9] G. Khrishnan and F. A. D. Gul, "Has Audit Quality Declined? Evidence From the Pricing of Discretionary Accruals," Working Paper, 2002.

[10] A. T. Craswell, J. R. Francis, and S. L. Taylor, "Auditor Brand Name and Reputations and Industry Specialization," Journal of Accounting and Economics, vol. 20, pp. 297-322, 1995

[11] Suhoko, Analisa Pengaruh Manajemen Laba Terhadap Return Saham Perusahaan LQ45, Fakultas Ekonomi Universitas Kristen Petra, 2009.

[12] T. Nurman, Pengaruh Praktik Earnings Management Terhadap Abnormal Return Saham, Fakultas Ekonomi Universitas Widyatama.2009

[13] K. Qiang, Q. Liu, and R. Qi, "Predicting Stock Market Returns with Aggregate Discretionary Accruals," Journal of Accounting Research, vol. 48, Issue 4, 2010.

[14] Ikatan Akuntan Indonesia (IAI), Standar Profesional Akuntan Publik, Penerbit Salemba Empat, Jakarta. 2007.

[15] K. Y. Chen, K. L. Lin, and J. Zhou, "Audit Quality and Earnings Management for Taiwan IPO Firms," Managerial Auditing Journal, vol. 20, no. 1, pp. 86-104, 2005.

[16] S. Balsam, "Accrual Management, Investor Sophisticated, and Equity Valuation: Evidence from 10-Q Fillings," Journal of Accounting Research, vol. 40, no. 4, pp. 987-1012, 2002
[17] A. D. M. D. Silveira and L. A. B. D. C. Barros, "Corrate Governance Quality and Firm Value in Brazil," Journal of Financial Economics. 2006.

[18] Nuryaman, "The Influence of Corporate Governance Practice on The Company's Financial Performance,” Journal of Global Business and Economic, Global Research.Com ISSN 2180-3625. vol. 5, no. 1, July 2012.

[19] P. M. Dechow, R. G. Sloan, and A. P. Sweeney, "Detecting Earnings Management," The Accounting Review, vol. 70, no. 2, pp. 193-225. 1995.

[20] J. R. Hair, Joseph, and R. E. Anderson, Multivariate Data Analysis. 7 th Edition, Prentice Hall International, Inc. United stated of America. 2010 .

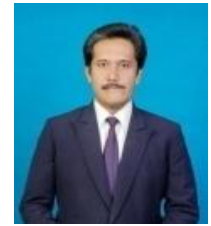

Nuryaman is currently senior lecturer of Widyatama University for Accounting Program, Magister Management Program (The Master degree), and Professional Accounting Education. He is a member of The Indonesian Institute of Accountans (IAI). With wide ranging research interests, he has published articles in several conference event and journals on his research both nationally and internationally. His current research interest focus on Corporate Governance, Financial Accounting, and Management accounting. Dr.Nuryaman can be contacted at nuryaman.nuryaman@gmail.com 